\title{
SCIDiC
}

\author{
International Journal of Dentistry and Oral Science (IJDOS) \\ ISSN: 2377-8075
}

\section{Analysis On TOMON (Tooth Monster Hunter) - A Gaming Tooth Brush In Improving Dental Hygiene Status and Behavior Of Children}

Research Article

Salikun $^{1^{*}}$, Ketut Harapan ${ }^{2}$, Marlindayanti ${ }^{3}$, Emma Kamelia $^{4}$

${ }^{1}$ Department of Dental Therapy and Hygiene, Poltekkes Kemenkes Semarang, Semarang50268, Indonesia.

${ }^{2}$ Department of Dental Therapy and Hygiene, Poltekkes Kemenkes Manado, Manado95163, Indonesia.

${ }^{3}$ Department of Dental Therapy and Hygiene, Poltekkes Kemenkes Palembang, Palembang, 30126, Indonesia.

${ }^{4}$ Department of Dental Therapy and Hygiene, Poltekkes Kemenkes Tasikmalaya, Tasikmalaya, 46196, Indonesia.

\section{Abstract}

Background: Tooth brushing is increasingly becoming a vital factor for keeping dental and oral hygiene. Children at five first years have a golden period of their development for learning skills. Parents face a barrier on the implementation of tooth brushing to their children. This paper outlines a new approach to presents "TOMON" or Tooth Monster Hunter for assisting the parents or medical staffs to help children for learning proper brushing skills through wearable tooth brush and its virtual game.

Method: The research is an experimental study with a pre-test and post-test control group design. Our research used a technological approach to create educational wearable sensor for children. This experimental method is testing cause and effect. The cause in this research is the TOMON game and the effect is dental hygiene status. We also analyse the brushing behaviour change of the children. The research was done in TK (kindergarten) Islam Al-Azhar 14, TK PGRI 75 Kramas and TK Nurus Sunnah Semarang.

Results: The results show that Debris Index of the experimental group change from the moderate category which is $66.7 \%$ and poor category which is $33.3 \%$ to all good category. In the control group, there is a change from the poor category which is $66.7 \%$ and the moderate category in $33.3 \%$ to all good category. The statistical analysis show that there is a significant change influence of TOMON in the brushing behaviour of children and dental hygiene status.

Keywords: Children; Debris Index; Dental And Oral Hygiene; TOMON.

\section{Introduction}

Damaged and untreated teeth and gums can cause dental and oral diseases such dental caries and tooth decay which interferes with other bodily health $[1,2]$. Globally, dental caries is the main prevalent disease and more common in children. Dental caries is preventable, and can be overcome by performing twice tooth brushing with fluoridated toothpaste [3]. In order to prevent dental caries, the control of plaque and debris is therefore essential since plaque is the primary etiological factor of dental caries. Tooth brushing has been identified as the most frequently used method of dental and oral hygiene and to prevent dental caries
[4]. Childhood has a golden period for the development especially for future learning skills, social and emotional abilities at first five years. Their brain constitute a "blossoming" period along with elaborative developmental action [5, 6]. Parents, in general, possess knowledge of tooth brushing for the children, yet many experience barriers to implement it to their children by not brushing the teeth of their children as recommended $[7,8]$.

It was reported in Indonesia National Basic Health Research (Riskesdas) that Indonesia's proportion of dental and oral problems in 2018 reached $57.6 \%$ with only $10.2 \%$ of medical staff. In general terms, it is known that the proportion of daily tooth

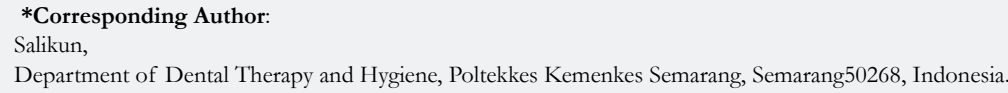

Citation: Salikun, Ketut Harapan, Marlindayanti, Emma Kamelia. Analysis On TOMON (Tooth Monster Hunter) - A Gaming Tooth Brush In Improving Dental Hygiene Status and Behavior Of Children. Int J Dentistry Oral Sci. 2021;08(04):2224-2229. doi: http://dx.doi.org/10.19070/2377-8075-21000440

Copyright: Salikun ${ }^{\circ} 2021$. This is an open-access article distributed under the terms of the Creative Commons Attribution License, which permits unrestricted use, distribution and reproduction in any medium, provided the original author and source are credited. 
brushing behaviour in the population aged more than 3 is $94.7 \%$ yet the proper tooth brushing behaviour showing only $2.8 \%$, $10]$.

Health education consists of learning experiences planned to form a voluntary action conducive to health. The scope of health education may include intervention, including to children. The goal of oral health is to improve knowledge, subsequently adopted to daily behaviour which contributes to better dental and oral hygiene [11]. A number of studies of maintaining dental and oral hygiene comprises leaflet method [12-15], flip book [16-18] or counselling $[19,20]$ have been done so far. However, an issue of knowledge was addressed that the methods have influence on attitude yet not to the change of knowledge or at certain time, it does not have influence when the treatment is stopped [18].

Along with the development of technology, gaming has become one method to support children's cognitive, physical, social and emotional well-being. Game also can increase the intrinsic motivation of the player. It is generally accepted that game can be preparation for children to improve their creativity, develop problem-solving skill. Game is potential for learning environment $[21,22]$. Dental game have been used as one method to help teach things about dentistry, such as dental practice management game [23], tooth morphology [24, 25], toothbrushes game [26, 27]. Smart Toothbrush has been made as an assistant in detecting human behaviour in maintaining healthy teeth in a vision-based system. This system cannot classify good and proper brushing of teeth [28]. The dental plaque estimation system using camera images has also been carried out as healthcare management. This method is used as a teaching tool for brushing teeth. The tool used is compatible with all types of cameras. However, it is still difficult to maintain individual dental health [29]. Children need a tool to play in order to develop their abilities [30].

The design of dental hygiene program should be performed to increase tooth brushing skill of children [31, 32]. In an attempt to do tooth brushing teaching, we made a tooth bushing game named TOMON (Tooth Monster Hunter) as an educational aid for dental hygiene game for children and analyse its influence to the dental hygiene status and the change of behaviour of children at kindergarten.

\section{Materials and Methods}

We undertook this research to an experimental studyconducted in 2019 in which the participants are TK (kindergarten) students. We used a pre and post-test design. There were two groups that are given different treatment with the aim to test the dental hygiene status both for the TOMON game treatment or not. This research was conducted at TK Islam Al-Azhar 14, TK PGRI 75 Kramas and TK Nurus Sunnah located in Semarang City, Indonesia. All the sample were 18 students in which experimental and control group consist of 9 students each.

Changes that were measured in this study are first, the status of dental hygiene with the standard Debris Index, second, is tooth brushing behaviour. The research was analysed by doing the calculation tabulation process. Next, an analysis of comparative studies on the results of dental health status was produced. We used paired sample T test analysis with MINITAB software. The $T$ test was used to test the effect of independent variable on the dependent variable. This test is done by comparing $\mathrm{T}$ arithmetic with $\mathrm{T}$ table. If the $\mathrm{p}$-value is less than 0.05 , then $\mathrm{H} 0$ is rejected, which means there is an influence of TOMON on dental hygiene. If the $\mathrm{p}$-value is more than 0.05 , then $\mathrm{H} 0$ is accepted which means there is no TOMONinfluence on dental hygiene status. In addition, the dental behaviour and health was analysed based on observations.

\section{Results}

Our game called TOMON (Tooth Monster Hunter) is an educational game based on android, which aims to stimulate the correct movement of brushing teeth. This game is played by 1 player (single player) and consists of 7 steps. Figure 1 shows one step of brushing the bottom left teeth. The player will be faced with monsters that stick to their teeth. The tooth image on the screen represents the player's teeth. Players are required to clean the entire surface of the teeth from monster attacks. Players are considered to win the game if they successfully clean the entire surface of the teeth from monster attacks.

The results comprise univariate and bivariate analysis. Univariate analysis tells about the frequency distribution of Debris Index and tooth brushing skill of experimental and control group. Subsequently, the bivariate analysis consist of Debris Index and tooth brushing skill analysis on experimental and control group.

Dental and oral hygiene can be measured using an index. The Index is a clinical condition which is obtained when an examination is held. The first set of analyses examined the status of dental and oral hygiene by OHIS (Oral Hygiene Index Simplified) score before and after the treatment is given. To assess OHIS, the standardization in calculating OHIS score is used according to the Ministry of Health of Republic of Indonesia Year 1995 through examination of debris on certain teeth and on certain surfaces of the teeth. The examination was divided in to 6 sextants in the buccal, lingual and palatal sections. The Debris Index assessment standards classified into good, moderate and poor category. Good

Figure 1. Brushing step: the monsters represent the dirty part of teeth and the gun shoots according to the movement of brushing.

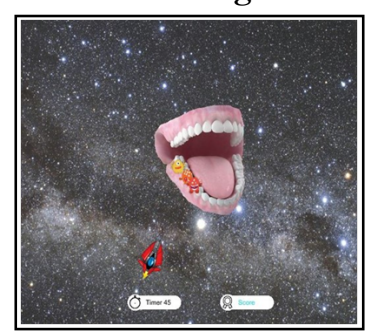


category stands on score 0 to 3.333. Moderate category stands on score 3.444 - 6.666 while Poor Category stands on 6.777 - 10 . The following tables show the statistical number related to this research.

Univariate analysis was done and details in Table 1-4. Table 1 shows the Debris Index of experimental group. The highest category of Debris Index of the experimental group before the treatment using TOMON game media is moderate in as much as $66.7 \%$, while after the treatment using TOMON, the highest percentage is in good category.

Table 2 shows the Debris Index of control group. Almost all of the frequency is categorized poor as much as $66.7 \%$. After the manual brushing, which means without treatment, the category change in to good, in $100 \%$.

Table 3 shows the brushing skill of experimental group. Before the treatment using TOMON, most of the category is moderate in $66.7 \%$, while after the treatment, the highest category is good with percentage of $77.8 \%$.

From the table 4, we can note the brushing skill of control group without using TOMON. Before brushing, most of the criteria is poor in $66.7 \%$, while after manually brushing, the criteria are still in poor category in $44.5 \%$.

Bivariate analysis details in Table 5 and 6. Table 5 lists the bivariate analysis on brushing skill. The first output on experimental group summarize that the mean treatment before treatment is 6.65 with a standard deviation of 1.52 while after the treatment is 0.257 with a standard deviation of 0.275 . Then the Mean value is greater before the treatment with difference of 6.393. The $T$ value is 12.41 with a degree of freedom of 16 and a P-value of 0.000 where this result is less than the critical limit of 0.05 so that the hypothesis answer is rejecting $\mathrm{H}_{0}$, meaning that there is a significant difference between before and after the treatment.

From the control group, the output shows that the mean treatment before is 7.41 with a standard deviation of 1.33 while the after treatment is 1.028 with a standard deviation of 0.727 . Then the Mean value is greater in the treatment before the difference of 6.382 .

It can be seen that the result at $\mathrm{t}$-arithmetic is 12.61 with a degree of freedom of 16 . It is seen that the p-value produced is 0,000 where the value is less than 0.05 so it is concluded that there is a significant difference between the Debris Index values before and after brushing teeth. As detailed can be seen, the significant differences before and after treatment in both the experimental and control groups give an idea that brushing has an effect on dental and oral hygiene.

Changes in the value of dental hygiene status affect the skill of brushing. The change in behaviour was assessed from a questionnaire filled out by the research team. The indicators used are the stages of brushing teeth from the right, left, top, bottom and front. The results of the ability to brush teeth are given in the form of tooth brushing practice. Skills are measured by adding up scores on the observation sheet with a score technique of yes $=$ 1 and no $=0$. Figure 2 presents TOMON game visual which has 7 game steps, so that a block of yellow dental reports will reduce the number of teeth that are brushed correctly. This tooth brushing skill assessment are brushing skills between the experimental groups that were given TOMON with the control group.

To indicate the results whether there is a significant comparison between Debris Index of the post-test of the experimental group and the control group, we conducted p-value test that produces the value detailed in Table 6.

Turning on now to the calculation results, it shows that the post Debris Index score on the experimental group is 0.257 with a standard deviation of 0.275 . While on post Debris Index score on the control group shows 1.028 with a standard deviation of 0.727 . The difference between the experimental and control group is -0.771 and the resulting $\mathrm{T}$ value is -2.98 , not to mention the $\mathrm{p}$ value is 0.009 . This value is less than the critical standard of 0.05 . That is, there is significant difference between the experimental and control group, meaning that Tooth Monster Hunter game

Table 1. Frequency Distribution of Debris Index Score of Experimental Group.

\begin{tabular}{|c|c|c|c|c|}
\hline \multirow{2}{*}{ Category } & \multicolumn{2}{|c|}{ Before } & \multicolumn{2}{c|}{ After } \\
\cline { 2 - 5 } & Frequency & $\mathbf{\%}$ & $\mathbf{f}$ & $\mathbf{\%}$ \\
\hline Good & 0 & 0 & 9 & 100 \\
\hline Moderate & 6 & 66.7 & 0 & 0 \\
\hline Poor & 3 & 33.3 & 0 & 0 \\
\hline Total & 9 & 100 & 9 & 100 \\
\hline
\end{tabular}

Table 2. Frequency Distribution of Debris Index Score of Control Group.

\begin{tabular}{|c|c|c|c|c|}
\hline \multirow{2}{*}{ Category } & \multicolumn{2}{|c|}{ Before } & \multicolumn{2}{c|}{ After } \\
\cline { 2 - 5 } & Frequency & $\mathbf{\%}$ & $\mathbf{f}$ & $\mathbf{\%}$ \\
\hline Good & 0 & 0 & 9 & 100 \\
\hline Moderate & 3 & 33.3 & 0 & 0 \\
\hline Poor & 6 & 66.7 & 0 & 0 \\
\hline Total & 9 & 100 & 9 & 100 \\
\hline
\end{tabular}


Table 3. Frequency Distribution of Brushing Skill of Experimental Group.

\begin{tabular}{|c|c|c|c|c|}
\hline \multirow{2}{*}{ Category } & \multicolumn{2}{|c|}{ Before } & \multicolumn{2}{c|}{ After } \\
\cline { 2 - 5 } & Frequency & $\mathbf{\%}$ & $\mathbf{f}$ & $\mathbf{\%}$ \\
\hline Good & 0 & 0 & 7 & 77.8 \\
\hline Moderate & 6 & 66.7 & 2 & 22.2 \\
\hline Poor & 3 & 33.3 & 0 & 0 \\
\hline Total & 9 & 100 & 9 & 100 \\
\hline
\end{tabular}

Table 4. Frequency Distribution of Brushing Skill of Control Group.

\begin{tabular}{|c|c|c|c|c|}
\hline \multirow{2}{*}{ Category } & \multicolumn{2}{|c|}{ Before } & \multicolumn{2}{c|}{ After } \\
\cline { 2 - 5 } & Frequency & $\mathbf{\%}$ & f & \% \\
\hline Good & 0 & 0 & 3 & 33.3 \\
\hline Moderate & 3 & 33.3 & 2 & 22.2 \\
\hline Poor & 6 & 66.7 & 4 & 44.5 \\
\hline Total & 9 & 100 & 9 & 100 \\
\hline
\end{tabular}

Table 5. Brushing Skill Analysis on Experimental and Control Group.

\begin{tabular}{|c|c|c|c|c|c|c|}
\hline \multirow[b]{2}{*}{ Variable } & \multicolumn{2}{|c|}{ Pre-test } & \multicolumn{2}{|c|}{ Post-test } & \multirow{2}{*}{$\begin{array}{c}\text { Mean } \\
\text { Treatment } \\
\text { Gap }\end{array}$} & \multirow[b]{2}{*}{$\mathbf{P}$-value } \\
\hline & $\begin{array}{c}\text { Mean } \\
\text { treatment }\end{array}$ & Std. D & $\begin{array}{c}\text { Mean } \\
\text { treatment }\end{array}$ & Std. D & & \\
\hline $\begin{array}{c}\text { Brushing skill on } \\
\text { Experimental Group }\end{array}$ & 6.65 & 1.52 & 0.257 & 0.275 & 6.393 & 0.000 \\
\hline $\begin{array}{l}\text { Brushing skill on } \\
\text { Control Group }\end{array}$ & 7.41 & 1.33 & 1.028 & 0.727 & 6.382 & 0.000 \\
\hline
\end{tabular}

Table 6. Debris Index Analysis on Experimental and Control Group.

\begin{tabular}{|c|c|c|}
\hline \multirow{2}{*}{ Variable } & \multicolumn{2}{|c|}{ Pre-test } \\
\cline { 2 - 3 } & Mean treatment & Std. D \\
\hline Debris Index on Experimental Group & 0.257 & 0.275 \\
\hline Debris Index on Control Group & 1.028 & 0.727 \\
\hline
\end{tabular}

Figure 2. Dental Report in Tooth Monster Hunter.

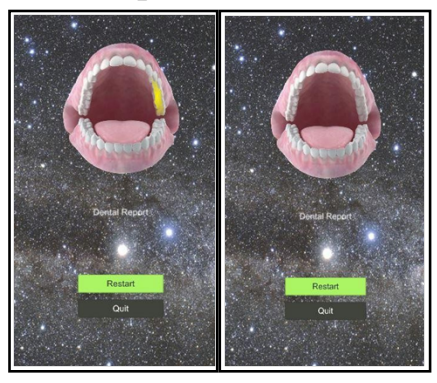

have an effect on children's dental hygiene status compared with a control group that was not given Tooth Monster Hunter game treatment.

\section{Discussion}

Dental caries affects $60-90 \%$ of school children as well as adults and more increasingly prevalent in developing countries including to some area in Asia and Latin America countries and the increase of information can boost the health status of patients [33, 34].
OHIS has designed primarily to quantify the status of oral health and one factor determining general health which includes Debris Index as determiner [35-37].

Further analysis showed that there is a change of Debris Index of the experimental group from the moderate category in $66.7 \%$ and poor in $33.3 \%$ to overall good. In the control group there is a change from the poor category of $66.7 \%$ and moderate which is $33.3 \%$ to all good. However, the percentage of reduction is significantly found in the experimental group, reaching $100 \%$. 
To prove whether there is a significant influence on the experimental group on pre and post-test, $\mathrm{p}$-value analysis was used. The results of paired $T$ test statistic obtained $\varrho$-value less than 0.05. This confirms that there is a significant difference to the Debris Index whenTOMON is given. The results of this study indicate that the educational media of the game TOMON has an effect on decreasing the children's Debris Index score compared to manual brushing. This is supported by the theory that game has a function that is useful in children, that is, children can understand computer technology so they can follow directions and rules, practice solving problems and logic, train motor nerves and spatial abilities [38].

The results of the study of tooth brushing skill on the experimental group show that there is a change from most in the moderate category of $66.7 \%$ to a good category in $77.7 \%$. On the control group, there is a change from the sufficient category of $66.7 \%$ to a good number of $33.3 \%$. The percentage increase in the group given Tooth Monster Hunter game is higher than the group that was not given counselling using Tooth Monster Hunter. To prove whether there is a significant influence on the experimental group before and after the Tooth Monster Hunter treatment was given; $\mathrm{p}$-value analysis was used. The results of paired $\mathrm{T}$ test statistic obtained $\varrho$-value less than 0.05 , which means reject $\mathrm{H}_{0}$, so it is concluded that there is a significant influence on teeth brushing skill using the TOMON game. This shows that the group given counselling using the TOMON game media has better skills than in the control group, because the TOMON game can increase children's active participation through game play so that the skills increase. The use of emerging tools in education are needed for educators. It is one of the effort to increase students' motivation as well as to enable them to practice in the real-world situation. $[39,40]$. So in fact, TOMON is effective to improve the status of dental hygiene and behaviour of tooth brushing. It enable the children to have a picture of proper tooth brushing in order to keep their dental hygiene.

\section{Conclusion}

Our work has led us to conclude that there is a significant influence on the dental hygiene status of children indicated by Debris Index with treatment using the game media TOMONS (Tooth Monster) in to the good category by the $\mathrm{p}$-value test that produces a value of 0.009 . Besides, there is a significant influence on the behaviour of tooth brushing in to the good and fair category with the p-value test producing a value of 0.014 . Taken together, these results suggest TOMON as educative media for teaching tooth brushing to children.

\section{Acknowledgement}

We would like to thank Poltekkes Kemenkes Semarang, Manado, Palembang and Tasikmalaya, Indonesia for the source of support. The source of funding for this research came from Poltekkes Kemenkes Semarang. The authors declare that they have no conflict of interest.

\section{References}

[1]. R. Fuccilo, B. Sharpe, and M. Laura Smith, Oral Health : An Essential Component of Primary Care, no. June. 2015.
[2]. Kumar S, Tadakamadla J, Johnson NW. Effect of toothbrushing frequency on incidence and increment of dental caries: a systematic review and metaanalysis. J. Dent. Res. 2016 Oct;95(11):1-7.

[3]. Marshman Z, Ahern SM, McEachan RR, Rogers HJ, Gray-Burrows KA, Day PF. Parents' experiences of toothbrushing with children: a qualitative study. JDR Clin Trans Res . 2016 Jul;1(2):122-30.

[4]. Hayasaki H, Saitoh I, Nakakura-Ohshima K, Hanasaki M, Nogami Y, Nakajima T, et al. Tooth brushing for oral prophylaxis. Jpn Dent Sci Rev. 2014 Aug 1;50(3):69-77.

[5]. Butchon R, Liabsuetrakul T. The Development and Growth of Children Aged under 5 years in Northeastern Thailand: a Cross-Sectional Study. J Child Adolesc Behav. 2017;5(1):1-6.

[6]. Brown TT, Jernigan TL. Brain development during the preschool years. Neuropsychol Rev. 2013 Dec 1;22(4):313-33.

[7]. de Jong-Lenters M, L'Hoir M, Polak E, Duijster D. Promoting parenting strategies to improve tooth brushing in children: design of a non-randomised cluster-controlled trial. BMC Oral Health. 2019 Sep 6;19(210):1-12.Pubmed PMID: 31492121.

[8]. Petrauskienė S, Narbutaitė J, Petrauskienė A, Virtanen JI. Oral health behaviour, attitude towards, and knowledge of dental caries among mothers of 0 - to 3-year-old children living in Kaunas, Lithuania. Clin Exp Dent Res. 2020 Apr;6(2):215-224.Pubmed PMID: 32250563.

[9]. Kementerian Kesehatan RI, “Hasil Utama Riskesdas 2018,” 2018.

[10]. Hadnyawati H. Pemanfaatan multimedia sebagai media penyuluhan kesehatan gigi. J. Dent. Indones. 2007 Dec 30;14(3):177-80.

[11]. Nakre PD, Harikiran AG. Effectiveness of oral health education programs: A systematic review. J Int Soc Prev Community Dent. 2013 Jul;3(2):103-115.

[12]. RE PP, Tauchid SN. Teaching Using The Demonstration Method At The Dental Brush Completely Compared To Leaflet And Poster Media On Score Debris Index Students On Classrooms Basic State Elementary School In South Jakarta. Simposium Nasional Ilmiah \& Call for Paper Unindra (Simponi). 2019:29-45.

[13]. Schlueter N, Klimek J, Saleschke G, Ganss C. Adoption of a toothbrushing technique: a controlled, randomised clinical trial. Clin. Oral Investig. 2010 Feb;14(1):99-106.

[14]. Al Bardaweel S, Dashash M. E-learning or educational leaflet: does it make a difference in oral health promotion? A clustered randomized trial. BMC oral health. 2018 Dec;18(1):1-8.

[15]. Mona D, Azalea FW. Leaflet and pocketbook as an education tool to change level of dental health knowledge. Bali Med. J. 2018 Sep 1;7(3):760-763.

[16]. T. Bramantoro et al., "Effectiveness of 3D Pop-up Fairytale Books as a Medium of Education to Improve the Basic Knowledge of Dental and Oral Health of Children Aged 4-5 Years," in Proceedings of The 7th International Meeting and The 4th Joint Scientific Meeting in Dentistry, 2018, pp. 191199.

[17]. Rikawarastuti R, Anggreni E, Budiarti R, Suid NR. The Use of "KakAyu Dental Flipbook" in Oral Health Knowledge Improvement for Elementary School Students in Depok. Kesmas Natl. Public Heal. J. 2017 May 24;11(4):163-7.

[18]. Gustina E, Wibowo M. Improving Knowledge and Changing Health Attitude among Teenagers through Digital Media Flipbook. J Sci Educ Technol. 2020 Feb 21;6(1):15-22.

[19]. H. J. Graesser, J. M. M. Kerry, A. De Silva, V. D. Swift, J. Satur, and S. Sofronoff, "Assessing the feasibility of a supervised toothbrushing program within breakfast clubs in Victorian Primary Schools," J. Dent. Oral Heal. Ther., vol. 7, no. 1, pp. 5-10, 2014

[20]. Brown RA. Training and assessment of toothbrushing skills among children with special needs.2012.

[21]. Elaldi S, Batdi V. The Effects of Different Applications on Creativity Regarding Academic Achievement: A Meta-Analysis. J. Educ. Train. Stud. 2016 Jan;4(1):170-9.

[22]. Goldstein J. Play in children's development, health and well-being. Brussels. Toy Ind. Eur. 2012 Feb.

[23]. Reisman A, Emmons H, Morito S, Rivaud J, Green EJ. Dental practice management game: a new tool for teaching practice management. J Dent Educ. 1977 May;41(5):262-7.Pubmed PMID: 265984.

[24]. A. Vahed, "The Tooth Morphology Board Game: An Innovative Strategy in Tutoring Dental Technology Learners in Combating Rote Learning," in Proceedings of the 2nd European Conference on Games Based Learning, 2008, no. October 2008, pp. 1-17.

[25]. A. Vahed, S. Singh, S. Mckenna. "Examining the Quality of Pedagogy through a Tooth Morphology Board Game," in Proceedings of the 8th European Conference on Games Based Learning (ECGBL). 2014; 2: 1-14.

[26]. Varga P. Playbrush-Transforming Toothbrushes Into Gaming Controllers. Front. Public Heal.2016;4.

[27]. Jacobson D, Jacobson J, Leong T, Lourenco S, Mancl L, Chi DL. Evaluating Child Toothbrushing Behavior Changes Associated with a Mobile 
Game App: A Single Arm Pre/Post Pilot Study. Pediatr Dent. 2019 Jul 15;41(4):299-303.Pubmed PMID: 31439090.

[28]. A. Flagg, J. Boger, and A. Mihailidis, "An Intelligent Toothbrush : Machines for Smart Brushing,” no. August 2016, 2017.

[29]. Kasai M, Iijima Y, Takemura H, Mizoguchi H, Ohshima T, Satomi N. Dental plaque assessment lifelogging system using commercial camera for oral healthcare. Annu Int Conf IEEE Eng Med Biol Soc. 2016 Aug;2016:25662569.Pubmed PMID: 28268846.

[30]. Rahma D. Penggunaan Alat Permainan Edukatif (Ape) Untuk Mendukung Perkembangan Anak Usia 5-6 Tahun Di Paud Al Fikri. Jurnal Pendidikan dan Pembelajaran Khatulistiwa. 2017;6(10).

[31]. Swain JJ, Allard GB, Holborn SW. The good toothbrushing game: a schoolbased dental hygiene program for increasing the toothbrushing effectiveness of children. J Appl Behav Anal. 1982 Spring;15(1):171-6.Pubmed PMID: 7096227.

[32]. Chang YC, Lo JL, Huang CJ, Hsu NY, Chu HH, Wang HY, et al. Playful toothbrush: ubicomp technology for teaching tooth brushing to kindergarten children. Proc. ACM CHI 2008 Conf. Hum. Factors Comput. Syst. 2008 Apr 6:363-372.

[33]. Nakre PD, Harikiran AG. Effectiveness of oral health education programs: A systematic review. J Int Soc Prev Community Dent. 2013 Jul;3(2):103-115.
[34]. O'Hehir T. Dental hygiene education exceeds the degrees granted: A pilot study. Int J Dent Hyg. 2018 Aug;16(3):1-9.Pubmed PMID: 29488313.

[35]. Wei SH, Lang NP. Periodontal epidemiological indices for children and adolescents: II. Evaluation of oral hygiene; III. Clinical applications. Pediatr Dent. 1982 Mar;4(1):64-73.Pubmed PMID: 6960328.

[36]. E. Rachmawati, D. N. Carolina, A. Susanto, I. Mustika, and R. S. Primarti, "Correlation between Oral Hygiene Index-Simplified (OHI-S ) and Various Body Mass Index ( BMI ) Among 6-8 Years Old Children in Bandung City," Int. J. Sci. Res., vol. 7, no. 1, pp. 2016-2019, 2018.

[37]. BEHBAHANI RA, Joulaei H, VOSOUGHI M, Golkari A. Assessing Oral Health Status and Behaviors in 6-Year-Old School Children in Rural and Urban Areas of Shiraz, Southern Iran.Int J School Health. 2015:1-8.

[38]. Putra DW, Nugroho AP, Puspitarini EW. Game Edukasi berbasis android sebagai media pembelajaran untuk anak usia dini. J. Inform. Merdeka Pasuruan. 2016 Mar 29;1(1):46-58.

[39]. Zirawaga VS, Olusanya AI, Maduku T. Gaming in Education: Using Games as a Support Tool to Teach History. J Educ Pract. 2017;8(15):55-64.

[40]. U. M. Mahdamy, "Aplikasi Education Game Berbasis Flash Untuk Pembelajaran Bahasa Inggris Bagi Anak -Anak,” Politeknik Telkom Bandung, 2011. 